\title{
Bourbon Virus in Wild and Domestic Animals, Missouri, USA, 2012-2013
}

\section{Katelin C. Jackson, ${ }^{1}$ Thomas Gidlewski, J. Jeffrey Root, Angela M. Bosco-Lauth, R. Ryan Lash, Jessica R. Harmon, Aaron C. Brault, Nicholas A. Panella, William L. Nicholson, Nicholas Komar}

Author affiliations: Centers for Disease Control and Prevention, Fort Collins, Colorado, USA (K.C. Jackson, A.C. Brault, N.A. Panella, N. Komar); US Department of Agriculture, Fort Collins (T. Gidlewski, J.J. Root); Colorado State University, Fort Collins (A.M. BoscoLauth); Centers for Disease Control and Prevention, Atlanta, Georgia, USA (R.R. Lash, J.R. Harmon, W.L. Nicholson)

DOI: https://doi.org/10.32301/eid2510.181902

Since its recent discovery, Bourbon virus has been isolated from a human and ticks. To assess exposure of potential vertebrate reservoirs, we assayed banked serum and plasma samples from wildlife and domestic animals in Missouri, USA, for Bourbon virus-neutralizing antibodies. We detected high seroprevalence in raccoons (50\%) and white-tailed deer (86\%).

$\mathrm{B}$ ourbon virus (BRBV) was first isolated from a febrile patient with a history of tick bites in Bourbon County, Kansas, USA; the patient later died from severe illness in 2014 (1). Several additional human BRBV infections were reported subsequently from the midwestern and southern United States (2). BRBV belongs to the family Orthomyxoviridae, genus Thogotovirus, which is distributed worldwide and includes Araguari, Aransas Bay, Dhori, Jos, Thogoto, and Upolu viruses $(1,3)$. Thogoto and Dhori viruses have been associated with human disease (4-6). Viruses within the genus Thogotovirus have been associated with hard or soft ticks (7). Recent studies suggest that the lone star tick (Amblyomma americanum) is involved with BRBV transmission $(2,3,8)$. These ticks feed primarily on mammals, which might play a role in BRBV ecology.

We evaluated banked animal serum and plasma for evidence of BRBV infection by using the plaque-reduction neutralization test (PRNT) to detect BRBV-reactive antibodies. We tested specimens of white-tailed deer (Odocoileus virginianus), raccoon (Procyon lotor), Virginia opossum (Didelphis virginiana), and various other mammals and birds from northwest Missouri, USA, for neutralizing antibodies against BRBV to identify naturally exposed host species and to implicate potential zoonotic amplifiers.

${ }^{1}$ Current affiliation: Washington State University, Pullman,

Washington, USA.
We collected specimens from wild and domestic vertebrates as described (9). We performed PRNTs on serum and plasma samples by using Vero cell culture as described (9). In brief, we initially screened samples by diluting them 1:5 and mixing them with an equal amount of BRBV suspension containing $\approx 100 \mathrm{PFUs} / 0.1 \mathrm{~mL}$. Samples that showed $\geq 70 \%$ reduction of plaques were confirmed by serial 2 -fold titration in duplicate from serum dilutions of 1:10-1:320. We considered $70 \%$ PRNT titers $\geq 10$ as positive.

We screened serum and plasma samples from 301 birds and mammals for BRBV-neutralizing antibodies. A total of $48(30.8 \%)$ of 156 mammalian serum samples were positive at the $70 \%$ neutralization level (Table). Mammals with evidence of past infection included domestic dogs, eastern cottontail, horse, raccoon, and white-tailed deer. None of 26 avian species were seropositive (Appendix Table, https:// wwwnc.cdc.gov/EID/article/25/9/18-1902-App1.pdf).

$\mathrm{BRBV}$ is probably transmitted to humans and other vertebrates by the lone star tick, an abundant arthropod in the southcentral United States (8). This virus was cultured from these ticks in northwestern Missouri in 2013 and eastern Kansas in $2015(2,8)$. Our results indicated that mammals are frequently exposed to BRBV. This finding was expected because lone star ticks feed primarily on mammals, and rarely on birds. Our study corroborates that birds are not involved in BRBV transmission, and our data establish that the vertebrate host range for infection now includes $\geq 5$ mammalian species, 2 of which are domestic animals (dogs and horses). Of the wildlife species, the seropositivity rate for white-tailed deer was high $(86 \%)$, whereas Virginia opossums, despite a moderate sample size $(n=28)$, showed no evidence of virus exposure. Deer and raccoons (seroprevalence $50 \%$ ) could be useful wildlife sentinels for tracking the geographic distribution of BRBV. Dogs (seroprevalence 15\%) and horses (seroprevalence 4\%) merit further consideration among domestic animals for use as sentinels for either tracking virus activity or as an early warning system for mitigation of human risk. Because of limited sampling, we observed no statistically significant difference in seroprevalence between these 2 species.

A limitation of our study was small sample sizes, which reduces the accuracy of the seroprevalence measurements. Furthermore, serologic data provide indirect evidence of virus infection, rather than the detection of the virus itself or its parts (i.e., antigen or nucleic acid). However, a closely related congener could exist and generate cross-reactive antibodies to BRBV, causing false-positive results in our assay. Nevertheless, the PRNT is generally considered the standard for serologic assays.

In conclusion, we have demonstrated that nonhuman vertebrates are exposed to BRBV. These findings are useful for future public health efforts and to better understand the ecology of BRBV. Specifically, we identified 2 candidate wildlife sentinels and potential domestic sentinels for tracking 
Table. PRNT 70 results for mammals tested for Bourbon virus-neutralizing antibodies, Missouri, USA, 2012-2013*

\begin{tabular}{lcccc}
\hline Common name & Species name & No. positive/no. tested & Titer & Proportion positive (95\% Cl) \\
\hline Domestic cat & Felis catus & $0 / 2$ & $<10$ & $0(0-0.66)$ \\
Domestic dog & Canis lupus familiaris & $2 / 13$ & $10-\geq 320$ & $0.15(0.04-0.42)$ \\
Eastern cottontail & Sylvilagus floridanus & $2 / 9$ & $\geq 320$ & $0.22(0.06-0.55)$ \\
Fox squirrel & Sciurus niger & $0 / 4$ & $<10$ & $0(0.0-0.49)$ \\
Horse & Equus caballus & $1 / 24$ & 20 & $0.04(0.007-0.20)$ \\
Raccoon & Procyon lotor & $31 / 62$ & $10-\geq 320$ & $0.50(0.38-0.62)$ \\
Virginia opossum & Didelphis virginiana & $0 / 28$ & $<(0.0-0.12)$ \\
White-tailed deer & Odocoileus virginianus & $12 / 14$ & $10-\geq 320$ & $0.86(0.60-0.96)$
\end{tabular}
${ }^{*}{ }^{*}$ RNT $70,70 \%$ plaque reduction neutralization titer.

and possible early warning of BRBV transmission risk. However, whether any of these mammalian species are competent amplifier hosts for BRBV remains to be determined.

\section{Acknowledgments}

We thank the property owners who granted access to their properties; the Missouri Departments of Health and Senior Services and Conservation, the Andrew County Health Department and participating veterinary clinics for providing assistance; David Ashley for providing laboratory space for specimen processing at Missouri Western State University; Luke Miller, Nathan Hubbard, and Sonja Weiss for assisting with mammal trapping; and Jason Velez for preparing Vero cell cultures for the neutralization assays performed.

\section{About the Author}

During this study, Ms. Jackson was an intern at the Division of Vector-Borne Diseases, National Center for Emerging and Zoonotic Infectious Diseases, Centers for Disease Control and Prevention, Fort Collins CO. She is currently a doctoral candidate at Washington State University, Pullman, WA. Her research interests include a One Health approach to zoonotic infectious diseases.

\section{References}

1. Kosoy OI, Lambert AJ, Hawkinson DJ, Pastula DM, Goldsmith CS, Hunt DC, et al. Novel thogotovirus associated with febrile illness and death, United States, 2014. Emerg Infect Dis. 2015;21:760-4. https://doi.org/10.3201/eid2105.150150

2. Savage HM, Burkhalter KL, Godsey MS Jr, Panella NA, Ashley DC, Nicholson WL, et al. Bourbon virus in field-collected ticks, Missouri, USA. Emerg Infect Dis. 2017;23:2017-22. https://doi.org/10.3201/eid2312.170532

3. Lambert AJ, Velez JO, Brault AC, Calvert AE, Bell-Sakyi L, Bosco-Lauth AM, et al. Molecular, serological and in vitro culturebased characterization of Bourbon virus, a newly described human pathogen of the genus Thogotovirus. J Clin Virol. 2015;73:127-32. https://doi.org/10.1016/j.jcv.2015.10.021

4. Butenko AM, Leshchinskaia EV, Semashko IV, Donets MA, Mart'ianova LI. Dhori virus - a causative agent of human disease: 5 cases of laboratory infection [in Russian]. Vopr Virusol. 1987;32:724-9.

5. Filipe AR, Calisher CH, Lazuick J. Antibodies to Congo-Crimean haemorrhagic fever, Dhori, Thogoto and Bhanja viruses in southern Portugal. Acta Virol. 1985;29:324-8.

6. Frese M, Kochs G, Meier-Dieter U, Siebler J, Haller O. Human MxA protein inhibits tick-borne Thogoto virus but not Dhori virus. J Virol. 1995;69:3904-9.
7. Hubálek Z, Rudolf I. Tick-borne viruses in Europe. Parasitol Res. 2012;111:9-36. https://doi.org/10.1007/s00436-012-2910-1

8. Savage HM, Godsey MS Jr, Tatman J, Burkhalter KL, Hamm A, Panella NA, et al. Surveillance for Heartland and Bourbon viruses in eastern Kansas, June 2016. J Med Entomol. 2018;55:1613-6. https://doi.org/10.1093/jme/tjy103

9. Bosco-Lauth AM, Panella NA, Root JJ, Gidlewski T, Lash RR, Harmon JR, et al. Serological investigation of Heartland virus (Bunyaviridae: Phlebovirus) exposure in wild and domestic animals adjacent to human case sites in Missouri 2012-2013. Am J Trop Med Hyg. 2015;92:1163-7. https://doi.org/10.4269/ ajtmh.14-0702

Address for correspondence: Nicholas Komar, Centers for Disease Control and Prevention, 3156 Rampart Rd, Fort Collins, CO 80521, USA; email: nck6@cdc.gov

\section{Fatal Case of Lassa Fever, Bangolo District, Côte d'Ivoire, 2015}

\author{
Mathieu Mateo, Caroline Picard, \\ Yahaya Sylla, Emilie Kamo, Danielle Odegue, \\ Alexandra Journeaux, Stéphane Kouassi Kan, \\ Marcelle Money, David N'Golo Coulibaly, \\ Eugène Koffi, Souleymane Meite, Véronique Akran, \\ Hervé Kadjo, Edgard Adjogoua, Solange N'Gazoa \\ Kakou, Sylvain Baize, Mireille Dosso
}

Author affiliations: Institut Pasteur, Lyon, France (M. Mateo, C. Picard, A. Journeaux, S. Baize); Centre International de Recherche en Infectiologie, Lyon (M. Mateo, C. Picard, A. Journeaux, S. Baize); Institut Pasteur de Côte d'Ivoire, Abidjan, Côte d'Ivoire (Y. Sylla, E. Kamo, D. Odegue, S.K. Kan, M. Money, D. N'Golo Coulibaly, E. Koffi, S. Meite, V. Akran, H. Kadjo, E. Adjogoua, S. N'Gazoa Kakou, S. Baize, M. Dosso)

DOI: https://doi.org/10.3201/eid2509.190239 